\title{
ETHICAL THEORY AND STAKEHOLDER- RELATED DECISIONS: THE ROLE OF STAKEHOLDER CULTURE
}

\author{
THOMAS M. JONES \\ WILL FELPS \\ GREGORY A. BIGLEY \\ University of Washington Business School
}

\begin{abstract}
We use convergent elements of major ethical theories to create a typology of corporate stakeholder cultures-the aspects of organizational culture consisting of the beliefs, values, and practices that have evolved for solving problems and otherwise managing stakeholder relationships. We describe five stakeholder cultures-agency, corporate egoist, instrumentalist, moralist, and altruist-and explain how these cultures lie on a continuum, ranging from individually self-interested (agency culture) to fully other-regarding (altruist culture). We demonstrate the utility of our framework by showing how it can refine stakeholder salience theory.
\end{abstract}

Stakeholder theorists view the corporation as a collection of internal and external groups (e.g., shareholders, employees, customers, suppliers, creditors, and neighboring communities)-that is, "stakeholders," originally defined as those who are affected by and/or can affect the achievement of the firm's objectives (Freeman, 1984). A major theme of stakeholder theory is the nature of the relationships between the firm (typically represented by its top managers) and stakeholders, whose interests often diverge considerably not only from those of the firm but also from each other. Early stakeholder theorizing was marked by some conceptual confusion, but Donaldson and Preston's (1995) three-part taxonomy-normative (How should the firm relate to its stakeholders?), instrumental (What happens if the firm relates to its stakeholders in certain ways?), and descriptive (How does the firm relate to its stakeholders?)-helped focus and clarify much stakeholder thinking. The normative questions are particularly important because they differentiate stakeholder theory from other prominent theories in organization science, such as resource dependence, managerial cognition, and institutional theories.

Although we do not take a normative stance per se, we do focus on the ways that firms manage relationships with stakeholders and handle

We gratefully acknowledge constructive comments on earlier versions of this paper by Robert Phillips, Shawn Berman, and three anonymous $A M R$ reviewers. trade-offs among competing stakeholder claims based on the ethical foundations of their corporate cultures. Further conceptual development regarding how firms manage stakeholder relationships seems warranted for two reasons. First, several distinct ethical frameworks have been advanced as potential foundations for managerial decision making with respect to stakeholder matters (e.g., Burton \& Dunn, 1996; Evan \& Freeman, 1988; Wicks, Gilbert, \& Freeman, 1994), raising questions about how these ethical fromeworks might be used jointly to inform a more general model. Second, whereas the focus of attention in stakeholder theory mainly has been on top managers, understood as relatively autonomous decision makers, these managers are often profoundly influenced by the organizational context in which they are embedded (Daft \& Weick, 1984; Katz \& Kahn, 1978; March \& Simon, 1958). This suggests a need to identify organization-level factors that could help us predict how firms manage stakeholder relationships.

Our paper addresses these two points. We first review the diverse ethical theories that have been applied to business and identify a convergent theme- $\alpha$ concern for the interests of others, as opposed to self-interest. We note that managers often feel tension between these two sentiments when they make stakeholder-related decisions, a tension frequently linked to and emanating from stakeholder attributes: power and legitimacy. Next, we describe an ethically 
based organization-level construct-stakeholder culture-that, we argue, helps resolve this tension and, more generally, influences managerial thinking and behavior with respect to stakeholder relationships. We then develop a punctuated continuum of five stakeholder cultures, ranging from fundamentally amoral cultures based on individual self-interest to limited morality cultures based on the advancement of shareholder interests and then to broadly moral cultures based on concern for the interests of all stakeholders. We explain how ethical theory might be linked, conceptually if not semantically, to the ethical frameworks commonly understood by corporate managers and, thus, to stakeholder cultures. Finally, to illustrate the value of the stakeholder culture construct, we show how it would alter the predictions yielded by Mitchell, Agle, and Wood's (1997) stakeholder solience model.

\section{ETHICAL FOUNDATIONS}

To explore possible elements of convergence in ethical theory, we briefly review the prominent perspectives, most of them the work of moral philosophers. We begin with a discussion of egoism, an approach to ethics that is essential to an understanding of ethical theory in general, followed by outlines of the basic tenets of utilitarianism, Kantion principles, Rawlsian fairness, rights, the ethics of care, virtue ethics, and integrated social contracts theory (ISCT). Later, we argue that corporate cultures, although they may not use the precise language of ethical theory, do have core values that roughly match those of these theories. Where available, we present evidence of common language versions of these ethical sentiments among managers and in firms.

\section{A Brief Review of Ethical Theory}

Egoism involves acting exclusively in one's own self-interest. Two forms of egoism are relevant to our discussion: psychological egoism and ethical egoism. On the one hand, psychological egoism-a descriptive theory of human behavior-holds that people are innately selfinterested and routinely act to advance their interests. Ethical egoism, on the other hand, is a normative perspective that holds that people ought to act exclusively in their self-interest.
This view posits that a person is obligated only to enhance his or her own long-term welfare and that commitments to others are not binding and should be reneged on if they cease to be advantageous to the individual (Beauchamp \& Bowie, 2004). The welfare of others is relevant to an egoist only if it affects his or her welfore; it has no independent moral standing.

Few moral philosophers endorse ethical egoism, and some would deny that it constitutes a normative theory at all (e.g., Barry \& Stephens, 1998). As noted below, a great deal of scholarship in moral philosophy and applied ethics is devoted to arguing that people (and organizations) ought to take the interests of others into account in their decision-making processes and behavior. Although the foundational principles, the arguments, the conclusions, and the behavioral prescriptions vary greatly among these theories, it is not much of an intellectual stretch to say that ethics is about other-regarding, rather than self-regarding, thought and behavior. Our focus is on the extent to which on organizational culture adopts self-interest or rejects it in favor of other-regarding sentiments, as reflected in the following theories.

Utilitarianism, based on the work of Hume (1740/2000), Bentham (1789/1996), and Mill (1863/ 1998), admonishes moral agents to promote overall human welfare by acting in ways that result in the greatest total beneficial consequences minus harmful consequences. Utilitarion theory applies this "cost-benefit" calculus universally-that is, to all who are affected by the decision, not just an individual (as in egoism) or an organization (as in corporate profit maximization). Utilitarianism takes two forms: act utilitarionism and rule utilitorionism. Act utilitorionism involves maximizing benefits relative to costs for the discrete decision in question. Rule utilitarionism involves following rules that are established in order to achieve the greatest net positive consequences over time.

Kantian ethics departs significantly from utilitarianism's focus on consequences; the focus instead is on principles-a deontological approach. Kant argued that human beings should be treated not simply as a means to one's own ends but also as ends in themselves. This emphasis on "respect for persons" stems from the view that human beings should be regarded as independent agents, with interests of their own and the judgment to act on them. In other words, they should be accorded the freedom to act au- 
tonomously. Kant gave great importance to motives for acting-making the right decisions for the right reasons being the ultimate goal. Kant was quite explicit regarding appropriate reasons for moral actions-that is, moral obligation. An act performed for reasons of personal satisfaction (or the benefit of the firm) carries less moral weight than it would if it were performed because of a duty to do so. Kant also argued that the principles ought to be universalizable; that is, if everyone adopted the principle, it should not be self-defeating. For example, if promise breaking were to become universal law, promises would have no meaning. The idea behind this prescription is that no moral code ought to apply only to oneself. Kant is also credited with the idea that principles ought to be reversible, a notion well-captured by the Golden Rule: "Do unto others as you would have them do unto you."

Rawlsian fairness considerations also entail a regard for others. In A Theory of Justice (197la), Rawls regards justice for the individual, not aggregate welfare, as the "first virtue" of social institutions. In colloquial terms, he is concerned more with how the pie is divided than with how large it is, a utilitarion concern. Although his arguments regarding distributive justice as fairness are intended to apply to social institutions (e.g., governmental policies), they may have implications for individuals and firms that make decisions regarding the distribution of economic benefits and burdens. Using the "social contract" as a heuristic device, Rawls argues that principles of justice ought to be arrived at by individuals making choices behind a "veil of ignorance"-an imaginary situation wherein the parties are ignorant of their own characteristics (advantages and disadvantages), thus rendering improbable the choice of principles that favor their own strengths and discount their weaknesses. The use of this device, intended to mitigate the effects of inequalities of initial circumstances over which people have no control and are, hence, undeserved, leads individuals to prefer a state of basic equality. This state of equality is then used as a point of comparison for alternative (unequal) states to determine their fairness. If everyone prefers an alternative distributive state to one of equality, it is considered just. Rawls' difference principle reflects his conclusion that inequalities are just only if they result in benefits for everyone, with particular emphasis on the least advantaged.

Rights theories have to do with securing or preserving certain liberties (negative rights) or benefits (positive rights) for their holders. The possession of a right by one party implies the existence of a corresponding duty or obligation on others' part. In the case of negative rights, that duty is to allow the party to act freely (not be interfered with) within the domain covered by the right. In the case of positive rights, the obligation is to provide the party with a benefit of some kind. Since rights often conflict with one another and there is no widely accepted hierorchy of rights, some moral philosophers have concluded that rights should be accorded prima facie validity. That is, rights should be respected unless there are good moral reasons for violating them; the moral force of a right depends on its "strength" in relation to other moral considerations applicable to the context in question.

The ethics of care derives from "feminist ethics" in general and the work of Gilligan (1982) in particular. This perspective focuses on personal relationships and the traits of personal character that create and sustain them-friendship, compassion, sympathy, empathy, faithfulness, and loyalty, for example. The focus on these human traits, which certainly qualify as virtues (as discussed below), deliberately eschews the emphasis on rules and calculations that characterize Kantian and utilitarian thought. Also absent are notions of universality and impartiality; the ethics of care regards actual relationships and the social contexts in which they are embedded as valid and important elements of ethical decision making. An ethical "dilemma" is not seen as an abstract problem with only one ethically "correct" solution that can be agreed on by impartial observers applying universally accepted principles. Instead, solutions can and should emerge from mutually caring relationships and the contexts in which the problems are embedded. Particular human beings in particular settings should generate "caring" solutions appropriate to unique situations.

Virtue ethics also focuses on human virtues, albeit a much longer list. For example, Pincoffs, giving new life to the ideas of Aristotle, offers a list of over six dozen virtues (1986: 85). He argues that the development of virtuous character should be a primary goal of the human condi- 
tion, and he identifies four classes of virtues: aesthetic, ameliorating, instrumental, and moral. Virtue ethics is about conditioning oneself to act morally as a matter of habit.

ISCT is a very recent addition to the normative ethics literature. Unlike other ethical theories that must be adapted to business settings, ISCT is intended to apply directly to them. Its most formal and complete articulation is found in Donaldson and Dunfee's book entitled Ties That Bind: A Social Contracts Approach to Business Ethics (1999). These authors use a social contracts perspective to show how individual communities can be allowed to develop their own (local) standards, within a "moral free space," as long as they (1) meet certain standards involving acceptance by community members and (2) do not violate broad, universal standards, called "hypernorms." As such, the theory attempts to simultaneously allow for a substantial diversity of adaptation to local conditions without allowing these developed norms to violate higher ethical standards.

In fact, the theory establishes an elaborate set of standards by which the propriety of these local norms should be judged. In order to be authentic, local norms must (1) have the consent of most members of the community, (2) allow exit from the community, and (3) allow "voice" in order to permit change in the norms, thus assuring that most members of the community regard them as binding. In turn, authentic norms are judged legitimate if they do not violate any hypernorms. Hypernorms are the result of "a convergence of religious, political, and philosophical thought" across a broad number of nations and cultures (Donaldson \& Dunfee, 1999: 44).

Finally, these authors offer a set of priority rules for choosing between/among competing legitimate norms. Legitimate norms that either do not conflict with or have priority over other legitimate norms are considered binding ethical standards. ISCT is quite different from the other theories described here, but, as discussed in the next section, it shares one important perspective with those theories.

\section{Convergent Elements in Ethical Theory}

Although the ethical theories reviewed above differ in important ways, they converge on one essential point-their emphasis on concern for others over self-interest. Because the extent of concern for others can differ as well, particularly in a corporate context, in a later section we develop a continuum of stakeholder cultures ranging from individually self-interested to exclusively other-regarding. Although we are the first to propose such a continuum at the organization level, theories of identity, leadership, and cooperation employ similar distinctions at the micro level. Identity theories posit that people con think of themselves as individuals or as part of larger collectives (Ashforth \& Mael, 1989), with only one level being active at a time (Lord, Brown, \& Freiberg, 1999). Walzer (1994) makes a distinction between "thin selves," concerned with narrow, short-term interests, and "thick selves," embedded in larger historical and social developments. In his view, moral reasoning and behavior are facilitated only by "thick" interpretations of self.

Similarly, some models of managerial leadership also contain references to collective-level versus self-level concepts. Transformational, charismatic, and visionary leaders may achieve success by activating their followers' sense of self at the collective level through articulation of a compelling moral mission (Shamir, House, \& Arthur, 1993). Shamir, Zakay, Breinin, and Popper (1998), Paul, Costley, Howell, Dorfman, and Trafimow (2001), and Sparks and Schenk (2001) provide additional support for this view. Models of cooperation also feature a prominent distinction between self-oriented and other-regarding behavior. Under the rubric of "social value orientation" (McClintock, 1978; Messick \& McClintock, 1968), cooperation researchers have identified four profiles in situations involving potential cooperation. Competitors try to maximize their outcomes relative to others. Individualists seek to maximize their absolute, not relative, outcomes. Cooperators try to maximize joint outcomes without being cheated themselves. And altruists try to maximize the other party's outcome with less concern for their own.

Clearly, scholars in other fields have found the contrast between narrow self-interest and a concern for others, narrow or broad, useful in explaining human behavior. We develop an analogous concept at the organization level-a continuum of stakeholder cultures based on the extent to which they are other-regarding. We propose that stakeholder culture is a potent organizational factor, profoundly influencing the way in which managers understand, prioritize, 
and respond to stakeholder issues and, as an example, how they establish stakeholder salience. As an introduction to these arguments, we offer a discussion of the moral tension between self-interest and the interests of stakeholders in managerial decision making.

\section{ETHICS, STAKEHOLDERS, AND MANATGERIAL DECISION MAKING}

Decision making with respect to stakeholder relationships can be fraught with tension. Trade-offs between firm interests and stakeholder interests, as well as those between or among the interests of different stakeholders, inherently involve the allocation of benefits and burdens among human beings and, hence, involve moral questions. Commonly, the tension that arises in this context is one of deciding whether to act in a self-regarding manner or in an other-regarding manner. Hendry (2004) not only captures this tension quite nicely but also mirrors our points of convergence in ethical theory, arguing that managers face two sets of conflicting prescriptions about how to act: traditional morality (obligation and duty, honesty and respect, fairness and equity, care and assistance) or market morality (self-interest).

In relationships with stakeholders, firms' selfinterest is often related to the exercise of power, without regard for moral concerns- $\alpha$ "might makes right" perspective. Power is well-defined for stakeholder relationships, by Willer, Lovaglia, and Markovsky, as "the structurally determined potential for obtaining favored payoffs in relations where interests are opposed" (1997: 573). To increase favorable outcomes for themselves, self-interested firms with power over their stakeholders will wield it with impunity. When confronted with stakeholder power, which may stem from resources that (1) are concentrated or tightly controlled, (2) are essential to operational performance, or (3) have no viable substitutes, self-interested firms will be responsive.

In contrast, traditional (other-regarding) morality may require that firms respond to stakeholders with legitimacy, which many stakeholder scholars consider a fundamentally moral phenomenon. In an integrative review of the legitimacy literature, Suchman (1995) posits the existence of three potential bases of legitimacy: pragmatic (similar to power), cognitive (habit- ual), and moral (positive normative evaluation). For most authors who address the issue of stakeholder legitimacy, however, the term is morally grounded. Mitchell et al. (1997) found that several (but not all) authors offered moral bases for stakeholder legitimacy (e.g., Carroll, 1979; Clarkson, 1995; Donaldson \& Preston, 1995; Evan \& Freeman, 1988; Langtry, 1994). This conclusion is not surprising, since basing legitimacy on power and/or habit would run counter to a central tenet of stakeholder theory-moral justifications for firm/stakeholder relationships (Donaldson \& Preston, 1995; Jones \& Wicks, 1999). Indeed, Donaldson and Preston conclude that "the central core of the [stakeholder] theory is, however, normative" (1995: 183). We highlight the moral foundation of stakeholder legitimacy because, as argued above, not all firms will treat moral claims in the same manner.

Our preferred account of stakeholder legitimacy is provided by Phillips (2003), whose analysis includes a compelling account of the link between legitimacy and power, a connection that becomes important in our discussion of the impact of stakeholder cultures on stakeholder salience. Phillips bases his notion of normative legitimacy on "stakeholder fairness" (Phillips, 1997), which, in turn, draws on the work of Hart (1955) and Rawls (1964, 197la,b). In this formulation, "obligations of fairness" are created whenever parties accept benefits of a mutually beneficial cooperative arrangement (Phillips, 1997: 57). Phillips (1997) also stipulates that participants make contributions and/or sacrifices to effect the arrangement and that "free riding" by participants is possible. When these conditions are met, stakeholders have normatively legitimate claims on the corporation (and vice versa). Although not all stakeholder theorists adopt this particular account of stakeholder legitimacy, almost all believe that corporations have moral obligations to address, in some way, the normatively legitimate claims of stakeholders.

Phillips (2003) also introduces the notion of derivative legitimacy. Derivative legitimacy is generated from a stakeholder group's power to affect the firm and its normatively legitimate stakeholders, even though that group has no normatively legitimate claims on the firm. Managerial attention to derivatively legitimate claims is morally justified by the responsibility managers have to protect the interests of the firm and its normatively legitimate stakehold- 
ers. Derivatively legitimate stakeholders-for example, the media, radical activist groups (terrorists, in the extreme case), and competitorscan affect the corporation in either beneficial or harmful ways. Indeed, most firms grant substantial salience to their competitors, even though they are certainly not normatively legitimate stakeholders. As Phillips puts it, normative legitimacy provides an answer to the question "For whose benefit... should the firm be managed?" (2003: 30) and is a primary form of legitimacy. From a moral perspective, the claims of derivatively legitimate stakeholders are secondary and should be addressed only when they affect the interests of normatively legitimate stakeholders. Firms concerned about their moral obligations will attend to the claims of both normatively and derivatively legitimate stakeholders. Moral obligations are central to our stakeholder culture construct, the topic to which we now turn.

\section{STAKEHOLDER CULTURES}

We argued above that when managers are faced with ethical decisions, they experience $a$ tension between self-interest, often bolstered by a "market morality" (Hendry, 2004), and otherregarding sentiments, as reflected in traditional moral principles. This tension is particularly intense in firm/stakeholder relationships because they are a critical venue for morally significant interactions. How can the tension be resolved? We contend that stakeholder culture, which, we argue, is a central facet of organizational culture, can provide managers with guidance regarding how this tension should be resolved. Stakeholder culture represents a firm's collective reconciliation of these contradictory motives in the past and, as such, consists of its shared beliefs, values, and evolved practices regarding the solution of recurring stakeholderrelated problems. Often, the "solution," found in the firm's stakeholder culture, is a relatively clear set of prescriptions about whether selfregarding or other-regarding norms will prevail, or whether some compromise between the two will hold sway.

In general, culture is a property of an organization constituted by (1) its members' taken-forgranted beliefs regarding the nature of reality, called assumptions; (2) a set of normative, moral, and functional guidelines or criteria for making decisions, called values; and (3) the practices or ways of working together that follow from the aforementioned assumptions and values, called artifacts (e.g., Geertz, 1973; Hatch, 1993; Pettigrew, 1979; Schein, 1985, 1990; Trice \& Beyer, 1984). Organizational culture reflects a sort of negotiated order (Fine, 1984) that arises and evolves as members work together, expressing preferences, exhibiting more-or-less effective problem-solving styles (Swidler, 1986), and managing, at least satisfactorily, external demands and internal needs for coordination and integration (Schein, 1990). Common experience in this regard can lead people, over time, to form shared and deeply ingrained (Denison, 1996) understandings about the way the organizational world works and the practices and standards that are appropriate and effective within that reality. In effect, culture represents an aspect of the organizational environment that helps members make sense of their own and others' behavior (Golden, 1992).

Corporate cultures are certainly made up of more than one cultural dimension; formalism, adaptability, and time horizon are prominent examples. However, a firm's stakeholders are the source of its most critical contingencies (Freeman, 1984). Indeed, Barney links successful corporate cultures to strong core values "about how to treat employees, customers, suppliers, and others"- that is, stakeholders (1986: 656). In addition, although it departs from our model somewhat by omitting employees, "external orientation" shows up as a central feature of most typologies of corporate cultures (Denison \& Mishra, 1995; Detert, Schroeder, \& Mauriel, 2000; Schein, 1990; VandenBerg \& Wilderom, 2004). Furthermore, the very inclusive inventory of stakeholders advanced by most stakeholder theorists-for example, Barney's (1986) list, plus shareholders and neighboring communitiesindicates that stakeholder relationships lie at the core of corporate operations. Consequently, solving stakeholder-related problems will be an important element of a company's overall culture.

In this paper, our focus is on what we call "stakeholder culture," which we define as the beliefs, values, and practices that have evolved for solving stakeholder-related problems and otherwise managing relationships with stakeholders. Although the extent to which organizational values and assumptions are widely 
shared and deeply held by organization members-that is, culture strength-can vary (e.g., Schein, 1985), the following arguments should gain force in proportion to culture strength. In addition, subcultures often exist within organizations (e.g., Martin, 2002). However, we focus on the organization-level variable and leave examination of stakeholder subcultures, and possible differential treatment of stakeholders across firm subunits, to future research.

Stakeholder culture is grounded in ethics and is based on a continuum of concern for others that runs from self-regarding to other-regarding. We argue that firms vary with respect to the extent and nature of their moral concern for their stakeholders and that this variation will often be linked, conceptually if not semantically, to the different moral philosophies. Importantly, we do not argue that corporate managers knowingly subscribe to, for example, utilitarian or Kantian ethical theories. However, many managers are aware of and subscribe to common language understandings of these ethical theories-understandings drawn from the norms of society at large and revealed in the ethical logics of organizations (e.g., Victor \& Cullen, 1988). Hence, these theories may become important sensemaking and sensegiving conduits through which stakeholder culture is communicated. Furthermore, as with cultures in general, stakeholder cultures are simultaneously the products of employee sentiments and reified "social facts" that have an independent effect on managerial decision making (e.g., Hatch, 1993).

Stakeholder culture is likely to affect how company employees assess and respond to stakeholder issues in two related ways: (1) by constituting a common interpretive frome on the basis of which information about stakeholder attributes and issues is collected, screened, and evaluated and (2) by motivating behaviors and practices-and, by extension, organizational routines-that preserve, enhance, or otherwise support the organization's culture. To begin with, collective cognitive structures, such as those derived from culture (e.g., assumptions and values), influence what data about the firm's external environment are noticed and what meaning is given to those data (e.g., Daft \& Weick, 1984). These structures filter and shape the enormous amount of stakeholder-related information that comes to bear on organizational participants. Culture helps people avoid infor- mation overload and make shared sense of (and take coordinated action in) complex and ambiguous situations. The practices constituting stakeholder culture reflect the collectively learned behavioral responses to problems that the organization has encountered as its members have worked together to manage complex stakeholder relationships. As such, these practices provide agreed upon heuristics that help managers take action, despite substantial complexity and ambiguity. Taken-for-granted elements within the culture give rise to a sort of "automaticity" (e.g., Bargh \& Ferguson, 2000) in the enactment of practices and routines in response to stakeholder issues and attributes.

Furthermore, the assumptions and values making up stakeholder culture may influence the nature and sophistication of the organizational practices used to monitor and interact with stakeholders (Hatch, 1993). For example, people tend to expend more time and effort collecting and interpreting data to elaborate on mental models relevant to important matters (Weick, 2004), such as for those directly related to core values of the culture. Consequently, organization members can be expected to (1) focus more specifically on, (2) collect more information about, (3) develop more comprehensive understandings of, and (4) create more sophisticated response routines around stakeholder issues germane to their firm's core values.

Stakeholder culture has antecedents in the literature on ethical context in business settings. Ethical climate refers to the prevailing perceptions of organizational values and the typical practices and procedures that have ethical content or pertain to moral behavior (Cullen, Parboteeah, \& Victor, 2003; Victor \& Cullen, 1988). Ethical culture consists of the "formal" (e.g., policies and procedures) and "informal" (e.g., peer behavior and norms) systems of behavioral control that are capable of promoting either ethical or unethical behavior (Treviño, 1990; Treviño \& Weaver, 2003). Clearly, ethical climate and ethical culture are related concepts. In fact, much of the research done under one tradition can inform the other, and, in combination, they address many topics of interest to organization scholars. Indeed, until Denison (1996) sorted out some of the key differences-"deep structure" values, beliefs, and assumptions (culture) versus surface-level understandings of organization members (climate), qualitative field 
studies (culture) versus quantitative surveys (climate), sociological basis (culture) versus psychological basis (climate)—scholars sometimes conflated organizational culture and organizational climate. For Victor and Cullen (1988), ethical climate represents the ethical aspect of organizational culture.

Our stakeholder culture construct differs from ethical climate/culture in two important ways. First, it is simpler. It focuses only on what matters to corporate stakeholders-whether or not the firm takes their interests into accountrather than trying to separate out the precise ethical foundation of that concern. We allow for multiple possible foundations.

Second, unlike previous work, stakeholder culture represents a clearly defined continuum of concern for stakeholder interests. Victor and Cullen (1998) employ a $3 \times 3$ matrix of categories, with "locus of analysis"-individual, local, and cosmopolitan-on the horizontal axis and "ethical criterion"-egoism, benevolence, and principle- on the vertical axis. Locus of analysis might suggest a continuum of concern for others, but the authors actually mean something quite different: sources of reference for ethical reasoning within the organization. Individual applies to personal moral standards, local to internal organizational sources, and cosmopolitan to sources outside the organization.

The three ethical criteria have different meanings across the three loci of analysis and, when combined with each locus, yield criteria that are quite ambiguous from a stakeholder group's point of view. While local egoism ("company profit") and cosmopolitan benevolence ("social responsibility") seem to be analogous to two of our categories (below), others clearly are not. For example, cosmopolitan egoism suggests a broad concern for stakeholders, but one form of this category is "efficiency," which, according to economic theory, would mean firm profit maximization without regard for the interests of nonshareholder stakeholders. Similarly, an example of cosmopolitan principles is "laws and professional codes," which again may have nothing to do with the interests of many stakeholders. Although these authors offer a credible typology of ethical climates/cultures, its implications for stakeholder relationships are unclear. Thus, we believe that stakeholder culture offers a better means of understanding firm/ stakeholder relationships from an ethical perspective.

\section{A Continuum of Stakeholder Cultures}

Although concern for others may be a conceptually continuous phenomenon, we argue that there are critical qualitative differences among firms that make a classification scheme meaningful. Our "punctuated" continuum (Table l) is based on critical differences in the culturebased solutions that firms may use to resolve the conceptual tension between self-interest and concern for others-sometimes made manifest by power and legitimacy, respectively.

We posit the existence of five categories of corporate stakeholder cultures, each characterized by a unique managerial orientation, presented in order of ascending concern for others. First, an amoral culture-agency culture-is based on managerial egoism and involves no concern for others. Next, two limited morality cultures-corporate egoist and instrumentalist (under the umbrella term moral stewardship) involve concern for the interests of shareholders but not for those of other stakeholders. Finally, two broadly moral cultures (another umbrella term)-moralist and altruist-involve concern for all corporate stakeholders.

\section{An Āmoral Culture}

Agency cultures are characterized by managerial egoism, the pursuit of self-interest at the individual level, even if the interests of the corporation and its shareholders, for whom managers nominally work, must be sacrificed. Agency cultures are essentially amoral, differentiated from other stakeholder cultures by an absence of moral concern for other economic actors. In agency theory, the "agency problem" stems from the separation of ownership and control, first documented by Berle and Means (1932). Selfinterest on the part of managers (agents) and shareholders (principals) is assumed, and agency theory (l) helps us better understand and predict the behavior of firms and their managers under various circumstances and (2) helps us design incentive structures and monitoring mechanisms that will better control managerial opportunism. Under this view, managers who fail to act in the interests of shareholders are not morally deficient. Rather, they are responding to 


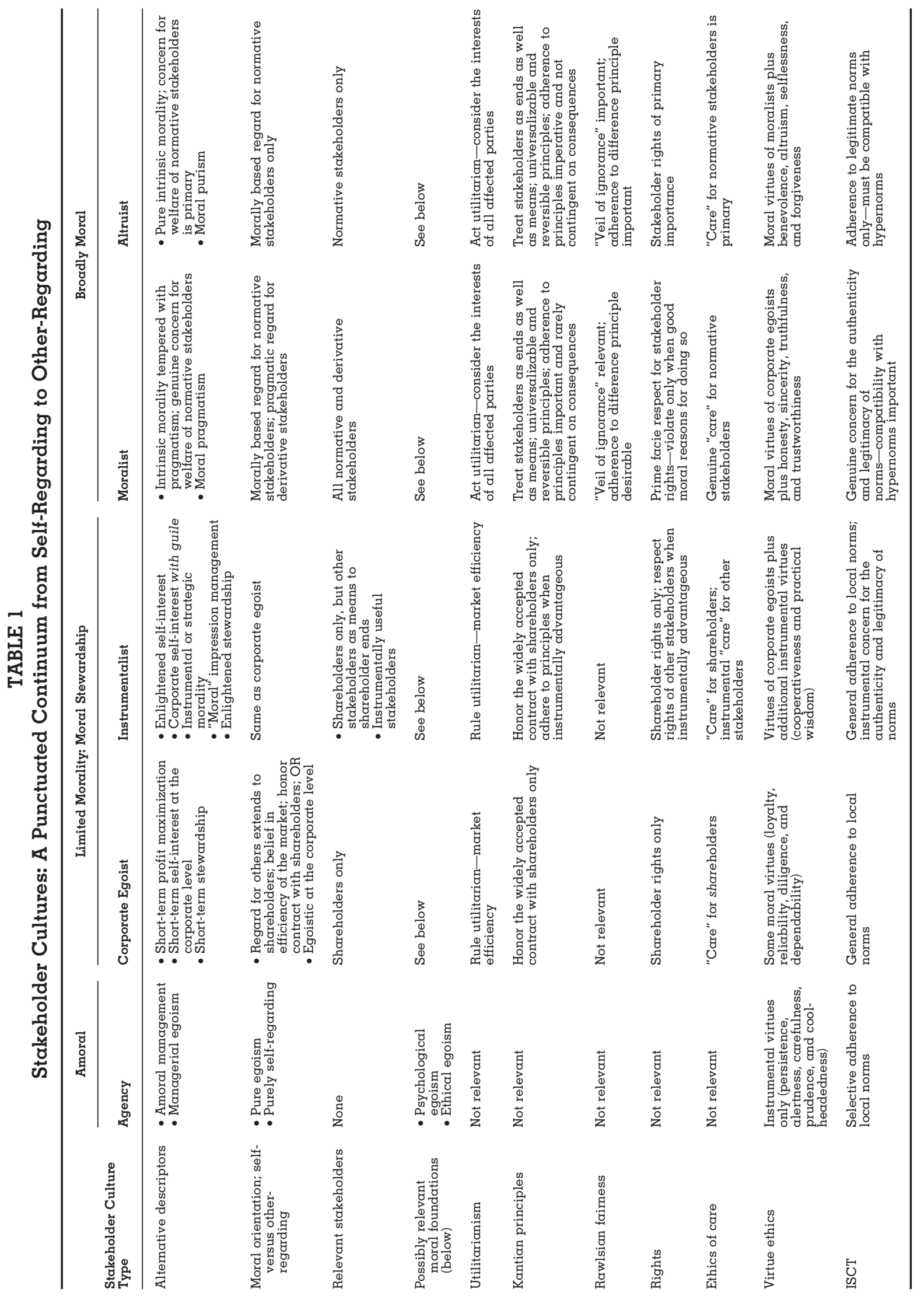


poorly designed incentive structures, or they are subject to inadequate monitoring mechanisms. "Moral" failures are attributed to faulty corporate governance, not faulty managerial ethics.

Shareholders may benefit from the actions of egoistic managers, but only as by-products of self-interested actions taken under incentive and monitoring regimes that properly align managerial and shareholder interests. Other stakeholders may benefit as well, depending on managerial incentives, but not in predictable ways based on the moral intentions of managers. Managerial egoists may have some instrumental virtues (Pincoffs, 1986), such as persistence, alertness, carefulness, prudence, and cool-headedness, but (in their managerial roles) will lack moral virtues found in managers in other-regarding cultures. Agency cultures are at the purely self-regarding end of our continuum of ethically grounded stakeholder cultures.

Self-interest will certainly play a major role in the stakeholder cultures of many firms, without any support from moral philosophers, perhaps taking the form of an "every person for him/ herself" mentality. Two studies have shown ample empirical evidence of individual egoism in organizations (Fritzsche \& Becker, 1984; Victor \& Cullen, 1988). We now turn to discussions of four other-regarding stakeholder cultures.

\section{Limited Morality Cultures: Moral Stewardship}

Moral stewardship (Davis, Schoorman, \& Donaldson, 1997) is our umbrella term for two stakeholder cultures-corporate egoist and instrumentalist-where managers have a limited moral commitment-protecting and advancing the interests of the owners of the corporation, its shareholders-rather than the amoral perspective of agency cultures.

One of the moral foundations of market capitalism is based on microeconomic models that have economic efficiency, a utilitarian concept, as their underlying goal. Managers who believe in "role responsibility" are implicitly invoking a form of rule utilitarianism under which they, acting in the interests of the firm and its shareholders by maximizing profits (or share value), play their appropriate role in an economy characterized by competitive markets, private property, perfect information, and so on. In short, they believe that Adam Smith's (1937) "invisible hand" is indeed able to transform self-interest into collective welfare. Milton Friedman, the Nobel Prize-winning economist, endorses this perspective in his provocative essay "The Social Responsibility of Business Is to Increase Its Profits" (1970). Managers who have made informed judgments regarding the ability of (even highly competitive) markets to produce socially optimal outcomes over time will regard moral stewardship as morally justified.

Moral stewardship may also be based on compliance with the terms of the principal/agent contractual arrangement, a Kantian moral perspective, wherein corporate managers (agents) are morally bound to advance the interests of their ultimate employers-the firm's shareholders (principals). Similarly, moral stewards may be concerned with the rights of shareholders and may even exhibit a form of empathetic (though not very proximate) "care" for their shareholders. In addition to the instrumental virtues listed above for egoistic managers, moral stewards, who aim to maximize profits (or shareholder wealth), might be loyal, reliable, diligent, and dependable in protecting and advancing shareholder interests.

Managers in moral stewardship cultures have a conceptually uncomplicated moral posture at the organization level-self-regarding and geared to maximize firm welfare. They are not guided by (1) act utilitarianism, which would require them to take into account possible consequences for all stakeholders, (2) the Kantion principles of universalizability, reversibility, or regarding stakeholders as ends as well as means, (3) Rawlsion fairness, (4) stakeholder rights, (5) "care" for stakeholders, or (6) the authenticity (let alone the legitimacy) of local community norms. They may consider the interests of nonshareholder stakeholders in an instrumental sense (depending on the form of stewardship involved, as described below) in making company decisions, but there is no moral commitment to these other stakeholders. Stakeholders (other than shareholders) are seen as means (or impediments) to the ends of the corporation. Managerial stewards behave according to the lessons taught in many business school classes: maximize shareholder wealth.

A concentrated focus on company profitability certainly describes a significant number of firms in modern economies and, hence, describes some corporate stakeholder cultures. Empirical evidence of thinking along steward- 
ship lines was found in two studies: (1) cosmopolitan egoism-striving for efficiency-and local egoism-profit maximization (Victor \& Cullen, 1988) and (2) rule utilitarianism (Fritzsche \& Becker, 1984). We now turn to descriptions of the two forms of stewardship cultures: corporate egoist and instrumentalist.

Corporate egoists are those firms whose cultures stress short-term profit maximization or its more recent manifestation, shareholder wealth maximization. Such firms regard the interests of stakeholders as important only to the extent that these stakeholders can contribute to the firm's short-term economic success, a perspective increasingly in evidence in today's quarterly results-driven corporate environment. Corporate self-interest without guile may be the best shorthand description of egoistic corporations. Corporate egoists aggressively contract with stakeholders (employees, suppliers, creditors, and customers) to compete effectively with other firms in their product markets. Stakeholder groups that can affect the firm's short-term profitability are dealt with in ways that work to the best advantage of the firm, through arm'slength transacting, zero-sum bargaining, highly specified contracting, litigation of contract disputes and ambiguities, opportunistic exploitation of contracting failures, and aggressive exploitation of power imbalances. Examples include hard bargaining (including soliciting competitive bids) over the prices suppliers receive for inputs to the firm's production processes and/or the prices customers pay for its products. Employees in egoistic cultures will be treated in ways that minimize labor costs, without falling too far short of industry norms in order to retain a competent workforce. Such firms will interpret laws in ways that favor company profitability. When the expected value of law breaking is positive, egoistic firms may consider law breaking a viable option.

Although egoistic firms exhibit amoral behavior to nonshareholder stakeholders, they are guided by the standards of moral stewardship of shareholder interests described above. Moral virtues such as loyalty, reliability, and dependability in the pursuit of shareholder interests could also characterize managers in corporate egoist cultures. Adherence to local norms (an ISCT concept), particularly those involving shareholders, may characterize egoistic firms as well.
Instrumentalist cultures subscribe to the doctrine of "enlightened self-interest" - $a$ voluntarily adopted "morality" that extends to those stakeholders that can enhance the firm's financial well-being. ${ }^{1}$ Friedman's (1970) classic article rejecting a broad social responsibility for corporations allowed for corporate actions providing broader social benefits, as long as these actions are undertaken in the service of shareholder interests. More recently, Jensen and Fuller (2002) wrote of "enlightened stakeholder theory," an approach that recognizes and advocates the management of firm/stakeholder relationships for the long-term enhancement of company economic performance.

Managers in instrumentalist cultures recognize that moral behavior (or the appearance thereof) is often beneficial to the firm, and they practice a form of strategic morality where they act "morally," but only to the extent that it is economically advantageous to do so. Such firms differ from corporate egoists in that they are opportunistic; self-interest with guile characterizes their behavior. Guile is Williamson's (1985) term for behavior intended to appear moral but with the underlying goal of advancing economic interests-that is, subtlety in the pursuit of economic gain (Frank, 1988; Quinn \& Jones, 1995). Put differently, the instrumentalist firm "invests" in longer-term benefits by foregoing the short-term opportunities of self-interested behavior. In contrast, the corporate egoist exploits short-term opportunities as they arise.

Instrumentalists are strategically "moral" only with respect to nonshareholder stakeholders. Like corporate egoists, they do have a moral commitment to the stewardship of shareholder interests and may be cooperative and "practically wise" (Pincoffs, 1986) in support of those interests-instrumental virtues that set them apart from corporate egoists. However, since opportunism may ultimately involve deceit, the moral virtues of honesty, sincerity, and truthfulness are unlikely to characterize instrumentalist stakeholder cultures.

\footnotetext{
${ }^{1}$ We present the terms moral and morality here in quotes because, as we explained above, not all moral philosophers (Kant, in particular) would regard "good" actions taken for the wrong reasons as moral.
} 


\section{Broadly Moral Cultures}

We also posit the existence of two stakeholder cultures-moralist and altruist-under the umbrella term broadly moral cultures. These cultures are extensively other-regarding in their decision making and attempt to adhere to moral principles that apply to all stakeholders, not just shareholders. Although moralist and altruist firms differ in terms of the compromises that sometimes must be considered under extreme circumstances, both try to take stakeholder interests into account, even when doing so does not appear to be in their self-interest-short or long term. They value honoring their commitments, adhering to the spirit and the letter of contractual obligations, and treating all stakeholders fairly and with respect. One possible way to distinguish instrumentalist cultures (described above) from broadly moral cultures is that the former may retain practices that explicitly weigh moral considerations against economic benefits. A classic example of these "taboo trade-offs" is putting a dollar value on human life (Tetlock, Kristel, Elson, Green, \& Lerner, 2000).

Broadly moral stakeholder cultures may originate with skepticism regarding (1) the ability of competitive markets to provide utilitarion outcomes over time and/or (2) the sanctity of the principal/agent contract. Examples that call the utilitarion results of market mechanisms into question are not difficult to find, but isolated examples do not render profit maximization an inappropriate application of rule utilitarianism, which focuses on costs and benefits over time. However, competitive markets actually create incentives to develop arrangements that allow firms to capture the benefits and force someone else to bear the costs. Ultimately, there can be no assurance that maximal social welfare will result. Managers who reach this conclusion may turn instead to act utilitarionism, where social welfore is pursued directly through discrete decisions rather than through obedience to rules. The role of their firms would then be to directly strive for overall economic and social wellbeing by considering the interests of all corporate stakeholders.

Although relatively few managers are likely to accept utilitarion theory wholesale, it is not uncommon for people to regard consequences for others as important elements in their moral decision making. That might mean expressing act utilitarion sentiments either at the personal level-"Are benefits for a few (including me) really worth burdens for many others?"-or at the public policy level-"This policy is good for the country, even if some are harmed (perhaps including me)." Therefore, taking the interests of others into account and aiming for the welfare of society as a whole might become elements of a corporate stakeholder culture. Indeed, two empirical studies show evidence of act utilitarion ethical sentiments in firms (Fritzsche \& Becker, 1984; Victor \& Cullen, 1988).

In a similar vein, managers may doubt the overriding sanctity of the contract between principals/shareholders and agents/managers, where shareholder interests trump the interests of all other stakeholders. Quinn and Jones (1995) have questioned the credibility of this position by arguing that it is logically incoherent and that other moral obligations take precedence over wealth-producing duties to shareholders. For these or other reasons, managers may feel that implicit contracts with other stakeholders are no less binding than the shareholder/ manager contract, and, therefore, they may adopt broader moral standards.

The Kantian notion of treating stakeholders as ends in themselves, as well as means to corporate economic ends, also constitutes a broader morality for corporations. Striving to uphold universally applicable principles ("What if all companies acted this way?"), behaving according to the Golden Rule, taking obligations seriously, and not acting as if conventional rules apply only to others are also Kantian notions that might resonate with the managers of broadly moral corporate cultures, as is the idea that worthy "principles" cannot be discarded simply because potential consequences to the firm may be negative. Victor and Cullen (1988) found that some managers regarded cosmopolitan principles as important elements of the ethical climates of their firms. Thus, Kantion principles might become a part of a stakeholder culture as well.

Some managers may respond to common language variants of Rawlsian notions, such as the veil of ignorance ("there but for fortune go I") or the difference principle ("help those less fortunate than yourself"). Many people do believe that the rights of others should be respected, creating the possibility of prima facie stake- 
holder rights. A genuine "care" for stakeholders, at least in a nonproximate empathetic sense, may also motivate broadly moral managers, as might the importance of such moral virtues as honesty, sincerity, truthfulness, and trustworthiness. Hence, Rawlsian notions of fairness, rights, care for others, and certain moral virtues could become elements of a stakeholder culture.

Finally, from on ISCT perspective, although the standards and evidence that would authenticate and then legitimize norms are certainly subject to debate (the proponents of ISCT offer many possibilities on both fronts) and are unlikely to be known to managers, a concern for the authenticity and legitimacy of norms is itself a revealing process. Managers may have moral reasons to question either the authenticity of the rules they play by ("Have other community members consented to these norms?") or their legitimacy ("Are these norms compatible with broader ethical standards?"). Managers who care about the propriety of the norms they adhere to would seem to have made a major step toward ethical behavior and a greater concern for their stakeholders. In contrast, managers who subscribe to norms simply because "that's the way things are done around here" have not adopted an other-regarding morality. Thus, a concern for the authenticity and the legitimacy of behavioral norms, like concerns for the broadly ethical perspectives described above, may be important elements of a firm's stakeholder culture.

Although the language and details of these moral philosophies may not be known to moral managers, the underlying sentiments of at least some of them will be. All of these notions are substantially other-regarding perspectives and involve attempts to "do the right thing," regardless of the consequences for the agent or firm. They differ from the stewardship-based cultures where the calculus of corporate self-interest is always present-straightforward in corporate egoist firms and more subtle in instrumentalist firms. Broadly moral firms do not routinely apply this calculus, because other-regarding concerns are paramount in their cultures.

Some firms do seem to have broadly moral cultures. Kotter and Hesket (1992) concluded that the managers of several highly successful firms tended to have a strong and genuine concern for such stakeholders as employees, customers, and suppliers, as well as shareholders. Post,
Preston, and Sachs have noted that "stakeholder-oriented firms often seem to be motivated by normative considerations that underlie a pervasive organizational commitment to humanistic values for their own sake" (2002: 79). In addition, empirical work has identified elements of social responsibility and respect for laws and professional codes (Victor \& Cullen, 1988), along with respect for rights and justice or fairness (Fritzsche \& Becker, 1984) among corporate managers. We now turn to descriptions of the two broadly moral cultures themselves: moralist and altruist.

Moralist cultures share the characteristics of broadly moral cultures: concern for all stakeholders and adherence to principles regardless of economic temptations to discard them. They will violate their moral standards only when it is necessary to ensure firm survival. In sharp contrast, instrumentalist firms will violate such standards whenever it is economically advantageous to do so. Whatever their source-act utilitarianism, Kantian principles, Rawlsian fairness concerns, respect for rights, "care" for stakeholders, ICST considerations, or a desire to be morally virtuous-ethical standards come first for moralist firms and are not trumped by economic considerations, except under the most dire circumstances.

When moralist firms make moral compromises in the face of financial crises, they do so for moral reasons. Tetlock et al. (2000) call the weighing of conflicting moral considerations a "tragic trade-off"- unfortunate, but necessary. These firms understand that the failure to respond to problems that threaten corporate survival will imperil all their stakeholders, whose well-being depends on the firm's economic viability. Moralist firms are moral, but pragmatic.

Altruist cultures are included for the sake of completeness. In altruist cultures other-regarding concerns are dominant. Moral principles trump all other decision-making criteria, even when firm survival is at stake, setting such firms apart from moralist firms. Altruist firms will honor obligations, explicit and implicit, and will always treat all of their stakeholders fairly and with respect. Moral standards-be they based on utilitarian, Kantian, Rawlsian, rights, care, virtue, or ISCT foundations-are decisive and not subordinate to pragmatic considerations. These firms are likely to regard as worthy the virtues of benevolence, altruism, selflessness, 
and forgiveness, in addition to the virtues found in other cultures. Adherence to moral principles alone, regardless of threats from powerful stakeholders, might be considered the "most moral" of our stakeholder cultures. However, our discussion of derivative legitimacy (above) clouds this conclusion; responding to derivatively legitimate stakeholders (powerful, but with no moral claim on the firm) when the interests of legitimate stakeholders are threatened may constitute a higher morality. We are agnostic on this issue.

The altruist culture completes our continuum, which now extends from fully self-regarding to fully other-regarding. As a practical matter, conditions of economic competition make significant growth or proliferation of fully otherregarding companies improbable.

We have now discussed the characteristics of five stakeholder cultures based on variation in the extent to which their moral standards are other-regarding. As in Table 1, adjacent cultures differ in terms of moral regard for an increasing number of stakeholder groups or a change in the subtlety with which their managers advance stakeholder interests. To illustrate the value of our general theory, we turn to a discussion of stakeholder salience (Mitchell et al., 1997).

\section{STAKEHOLDER SALIENCE REVISITED}

Mitchell et al.'s (1997) stakeholder salience theory is an attempt to "get inside the heads of corporate managers" to determine what they really pay attention to as they weigh stakeholder concerns in their corporate policy deliberations-colloquially, "who or what really counts." In this typology the three principal determinants of salience-power (the ability of the stakeholder group to bring about outcomes that it desires, despite resistance), legitimacy (the extent to which the stakeholder group's relationship with the firm is socially accepted and expected), and urgency (the degree to which the stakeholder group's claim is time sensitive and of critical importance to the group)-combine linearly to produce seven different types of stakeholder groups, each with a predicted level of salience for managers of the firm in question. The left side of Table 2 presents the same information as Mitchell et al.'s (1997) Venn diagram; the right side represents our modification of their stakeholder salience theory.

Table 2 makes the additive nature of the model apparent; the more attributes possessed by the stakeholder group, the greater the salience for managers. All three attributes (definitive stakeholders) result in high salience. Two attributes (dominant, dangerous, and dependent stakeholders) result in moderate salience. One attribute (dormant, discretionary, and demanding stakeholders) results in low salience. Groups with none of these attributes are not considered stakeholders and possess no salience.

\section{Incorporating Stakeholder Culture into the Salience Model}

This model is parsimonious and has intuitive appeal. Nevertheless, a closer look at its implications suggests some possibilities for extension and refinement. As noted above, managers

TABLE 2

Comparison of Stakeholder Salience Models

\begin{tabular}{|c|c|c|c|c|c|c|c|}
\hline \multicolumn{3}{|c|}{ Stakeholder Attributes } & \multirow{2}{*}{$\begin{array}{l}\text { Mitchell et al. } \\
\text { (1997) } \\
\text { Stakeholder } \\
\text { Type }\end{array}$} & \multirow{2}{*}{$\begin{array}{l}\text { Mitchell et al. } \\
\text { (1997) } \\
\text { Stakeholder } \\
\text { Salience }\end{array}$} & \multicolumn{3}{|c|}{ Stakeholder Culture Type } \\
\hline Power & Legitimacy & Urgency & & & Corporate Egoist & Instrumentalist & Moralist \\
\hline Yes & Yes & Yes & Definitive & High & High & High & High \\
\hline Yes & Yes & No & Dominant & Moderate & Moderate & Moderate & Moderate \\
\hline No & Yes & Yes & Dependent & Moderate & None & Moderate & High \\
\hline Yes & No & Yes & Dangerous & Moderate & High & High & Moderate \\
\hline Yes & No & No & Dormant & Low & Moderate & Moderate & Low \\
\hline No & Yes & No & Discretionary & Low & None & Low & Moderate \\
\hline No & No & Yes & Demanding & Low & None & None & None \\
\hline No & No & No & Nonstakeholder & None & None & None & None \\
\hline
\end{tabular}


of firms with different stakeholder cultures may prioritize power and legitimacy differently, suggesting the value of an extended model of stakeholder salience that includes the effects of stakeholder culture. In our extension we retain the three-attribute structure-power, legitimacy, and urgency-developed by Mitchell et al. (1997). However, the moral nature of legitimacy, developed above, is given more prominence here. We also agree with these authors' contention that stakeholder salience is the result of managerial perceptions-psychological constructions of reality by managers, based partly on features of their environments. However, we classify these psychological constructions more specifically in terms of stakeholder culture.

In the following sections we describe how stakeholder cultures differentially influence the perceptions of managers regarding the ascription and subsequent weighting of the three attributes (power, legitimacy, and urgency) of the claims of stakeholder groups. In general, our analysis posits that responding to power is simply rational self-regarding behavior, whereas responding to legitimacy derives from otherregarding (moral) sentiments. We focus on the three "central" culture types-corporate egoist, instrumentalist, and moralist-for two reasons. First, the agency culture, grounded in the principal/agent relationship and its assumption of self-interest, is extensively described in the financial economics/agency theory literature. The salience of stakeholder claims will depend on the incentive structures faced by managers as individuals and will be unpredictable at the organization level. Other than placing agency cultures on our stakeholder culture continuum, we have nothing to add. Second, altruist cultures, those that take uncompromisingly principled moral positions in stakeholder relationships, will play a small role in a competitive economy. The three central culture types, because they place differential importance on the three attributes, have stakeholder salience hierarchies that differ from one another and from those of the original model, as shown on the right side of Table 2 .

\section{Corporate Egoist Cultures and Stakeholder Salience}

As noted above, the defining ethical feature of the corporate egoist culture is the primacy of short-term shareholder wealth maximization. Since powerful stakeholders are most able to adversely affect corporate outcomes, power will be the primary driver of stakeholder salience for corporate egoists. Shareholders with large holdings, workers with strong unions, high-volume customers with alternative sources of supply, and governmental agencies with relevant regulatory powers are likely to be salient to these firms. Corporate egoist firms are likely to have sophisticated mechanisms in place dedicated to gathering and processing information related to powerful stakeholders. Consequently, they will understand power considerations quite well. If their stockholders include institutional investors with large holdings, then routines and systems, such as an office of investor relations, will be created to manage and influence these investors. However, diffused stock ownership represents less power and will warrant less attention.

Furthermore, powerful stakeholders with time-sensitive and critically important claims (urgency) merit special consideration, since they are the ones most likely to place intense demands on the firm. Thus, urgency is a booster of salience based on power. Claims combining power and urgency (i.e., definitive and dangerous stakeholders) are predicted to be highly salient to corporate egoists. Since powerful stakeholders can hinder the pursuit of profit maximization on grounds other than urgent claims on the company (Frooman, 1999), power without urgency (dominant and dormant stakeholders) will generate moderate salience. Legitimate claims are irrelevant in the corporate egoist's culture, as are urgent claims in the absence of power. Hence, dependent, discretionary, and demanding stakeholders will not merit attention, because neither they nor their claims are particularly valued or well-understood. Managers in egoistic cultures are "blind" to these issues because of (1) a clear prioritization of powerful stakeholders and (2) underdeveloped systems for dealing with them.

Proposition 1: Managers in corporate egoist cultures will always regard the interests of powerful stakeholders as at least moderately salient; they will regard these interests as highly salient when the claims are also urgent. 


\section{Instrumentalist Cultures and Stakeholder Salience}

Instrumentalist firms place preeminent value on the pursuit of corporate self-interest with guile. Other terms used to convey this orientation are enlightened self-interest, pragmatic morality, and strategic morality. Instrumentalist firms will try to capture the benefits of moral behavior (Frank, 1988; Jones, 1995) without abandoning their fundamental self-interest. Consequently, power will be a primary driver of salience, because corporate self-interest lies at the heart of the firm's instrumentalist posture. However, because the firm sees moral behavior as instrumentally useful (up to a point), it will regard legitimacy as a secondary determinant of salience as well. Again, urgency is a booster of salience generated from either power or legitimacy. Hence, definitive and dangerous stakeholders will certainly be highly salient to managers of instrumentalist firms because of their power and urgency.

Unlike corporate egoists, however, firms with instrumentalist cultures will regard the claims of dependent stakeholders (legitimate and urgent) as moderately salient as well and may pay some attention (low salience) to discretionary (legitimate, but not urgent) stakeholders, simply because of the perceived long-term benefits associated with moral behavior. These benefits might include currying fovor with other powerful groups that have a strong preference for trustworthy companies (e.g., customers, governmental agencies) or, conversely, avoiding the negative public relations that might come from treating legitimate stakeholders poorly. In a sense, instrumentalist firms may grant legitimate stakeholders a form of "derivative power," analogous to derivative legitimacy as discussed above.

Proposition 2a: Managers in instrumentalist cultures will always regard the interests of powerful stakeholders as at least moderately salient; they will regard these interests as highly salient when the claims are also urgent.

Proposition 2b: Managers in instrumentalist cultures will always regard the interests of legitimate stakeholders as at least somewhat salient (low salience); they will regard these interests as moderately salient when the claims are also urgent.

\section{Moralist Cultures and Stakeholder Salience}

Moralist firms have a genuine concern for stakeholder interests, making legitimacy the primary driver of salience for their managers. However, moralist firms are also sensitive to power issues, since power may give stakeholders derivative legitimacy (discussed above), a secondary driver of salience. Since urgency provides impetus for stakeholders and firms alike to deal with legitimate concerns, it is a booster of salience generated by either legitimacy or power. Combinations of legitimacy and urgency (definitive and dependent) will be highly salient to moralist firms. Stakeholders with these attributes include shareholders, when profitability is threatened; customers affected by product quality; local communities affected by plant operations; and employees, when threats to their livelihood are present. Legitimacy without urgency still carries moral weight, so dominant, dependent, and discretionary stakeholders will be viewed as moderately salient. Note that if instrumentalist firms (above) are good at strategic "morality," their behavior may be similar to that of moralist firms for a time. Both are likely to be responsive to power and legitimacy, albeit from different sources-self-interest/opportunism in the former case and a moral concern for legitimacy (normative or derivative) in the latter.

Proposition 3a: Managers in moralist cultures will always regard the interests of legitimate stakeholders as at least moderately salient; they will regard these interests as highly salient when the claims are also urgent.

Proposition 3b: Managers in moralist cultures will always regard the interests of powerful stakeholders as at least somewhat salient (low salience); they will regard these interests as moderately salient when the claims are also urgent.

The right-hand side of Table 2 pulls all of these revised predictions together for corporate egoist firms, instrumentalist firms, and moralist firms and summarizes our theoretical contribu- 
tions to stakeholder salience. A simple overview of this part of the table is as follows. Acting alone, attributes that are of primary importance to a firm (power or legitimacy), based on its stakeholder culture, generate moderate salience. Derivative attributes (legitimacy or power) are secondary drivers and, acting alone, generate low salience. In either case, urgency acts as a booster of salience (low to moderate; moderate to high), determined by primary or derivative attributes, but generates no salience by itself.

It is clear from this table that our predictions of stakeholder salience are significantly affected by stakeholder culture and that they differ substantially from those advanced in Mitchell et al.'s (1997) original work. Particularly noteworthy are the differential responses to power by corporate egoist firms and moralist firms. Without power, no stakeholder group can expect to be at all salient to the corporate egoist, whereas two stakeholder groups without power-dependent and discretionary-can expect high and moderate salience, respectively, from moralist firms, based on their legitimacy.

\section{DISCUSSION AND CONCLUSIONS}

There are three major contributions of this paper. First, we identified and developed a framework that highlights points of convergenceself-regarding versus other-regarding-in several otherwise diverse approaches to business ethics. Second, we used this framework to create a continuum punctuated by five corporate stakeholder cultures-organization-level phenomena that guide managerial thinking and decision making with respect to stakeholder relationships. Third, as an illustrative example, we applied our stakeholder culture construct to stakeholder salience theory and noted the emergence of significantly revised predictions of salience.

With respect to contributions of specific interest for stakeholder theorists, the combination of points one and two above represents an important integration of normative and descriptive elements of the theory. That is, the way a firm's managers actually respond to stakeholder issues is interwoven with notions of how they should respond. Also, with a firm-level perspective on salience, we can understand how a collection of managers in a firm will think about and respond to different stakeholder issues, moving us beyond the individual values of CEOs, as used in previous research (Agle, Mitchell, \& Sonnenfeld, 1999). In addition, our approach explains an empirical result discovered by these authors; urgency is really a secondary attribute that merely provides the "extra push" needed to make already salient issues more so. While power and legitimacy both have their champions-corporate egoist and moralist firms, respectively-urgency does not. In summary, this theoretical contribution, especially in conjunction with subsequent empirical work, could be an important element in the larger cause of understanding ways for stakeholders and firms to cooperate for mutual gain (Freeman, 1984).

\section{REFERENCES}

Agle, B. R., Mitchell, R. K., \& Sonnenfeld, J. A. 1999. Who matters to CEOs? An investigation of stakeholder attributes and salience, corporate performance, and CEO values. Academy of Management Journal, 42: 507-525.

Ashforth, B. E., \& Mael, F. 1989. Social identity theory and the organization. Academy of Management Review, 14: 2039.

Bargh, J. A., \& Ferguson, M. J. 2000. Beyond behaviorism: On the automaticity of higher mental processes. Psychological Bulletin, 126: 924-945.

Barney, J. B. 1986. Organizational culture: Can it be a source of sustained competitive advantage? Academy of Management Review, 11: 656-665.

Barry, B., \& Stephens, C. U. 1998. Objections to an objectivist approach to integrity. Academy of Management Review, 23: 162-169.

Beauchamp, T. L., \& Bowie, N. E. 2004. Ethical theory and business. Upper Saddle River, NJ: Prentice-Hall.

Bentham, J. 1996. (First published in 1789.) An introduction to the principles of morals and legislation. (Edited by J. H. Burns \& H. L. A. Hart.) New York: Oxford University Press.

Berle, A. A., \& Means, G. C. 1932. The modern corporation and private property. New York: Commerce Clearing House.

Burton, B. K., \& Dunn, C. P. 1996. Feminist ethics as moral grounding for stakeholder theory. Business Ethics Quarterly, 6: 133-148.

Carroll, A. B. 1979. A three-dimensional conceptual model of corporate social performance. Academy of Management Review, 4: 497-505.

Clarkson, M. 1995. A stakeholder framework for analyzing and evaluating corporate social performance. Academy of Management Review, 20: 92-117.

Cullen, J. B., Porboteeah, K. P., \& Victor, B. 2003. The effects of ethical climates on organizational commitment: A twostudy analysis. Journal of Business Ethics, 46: 127-141. 
Daft, R. L., \& Weick, K. E. 1984. Toward a model of organizations and interpretation systems. Academy of Management Review, 9: 284-295.

Davis, J. H., Schoorman, F. D., \& Donaldson L. 1997. Toward a stewardship theory of management. Academy of Management Review, 22: 20-47.

Denison, D. R. 1996. What is the difference between organizational culture and organizational climate? A native's point of view on a decade of paradigm wars. Academy of Management Review, 21: 619-654.

Denison, D. R., \& Mishra, A. K. 1995. Toward a theory of organizational culture and effectiveness. Organization Science, 6: 204-223.

Detert, J. R., Schroeder, R. G., \& Mauriel, J. J. 2000. A framework for linking culture and improvement initiatives in organizations. Academy of Management Review, 25: 850-863.

Donaldson, T., \& Dunfee, T. W. 1999. Ties that bind: A social contracts approach to business ethics. Boston: Harvard Business School Press.

Donaldson, T., \& Preston, L. E. 1995. The stakeholder theory of the corporation: Concepts, evidence, and implications. Academy of Management Review, 20: 65-91.

Evan, W. M., \& Freeman, R. E. 1988. A stakeholder theory of the modern corporation: Kantian capitalism. In T. Beauchamp \& N. Bowie (Eds.), Ethical theory and business (2nd ed.): 75-93. Englewood Cliffs, NJ: PrenticeHall.

Fine, G. A. 1984. Negotiated orders and organizational cultures. Annual Review of Sociology, 10: 239-262.

Frank, R. 1988. Passion within reason: The strategic control of the emotions. New York: Norton.

Freeman, R. E. 1984. Strategic management: A stakeholder approach. Boston: Pitman

Friedman, M. 1970. The social responsibility of business is to increase its profits. New York Times, September 13: 3233, 122-126.

Fritzsche, D. J., \& Becker, H. 1984. Linking management behavior to ethical philosophy. Academy of Management Journal, 27: 166-175.

Frooman, J. 1999. Stakeholder influence strategies. Academy of Management Review, 24: 191-214.

Geertz, C. 1973. The interpretation of cultures: Selected essays. New York: Basic Books.

Gilligan, C. 1982. In a different voice. Cambridge, MA: Harvard University Press.

Golden, B. R. 1992. The past is the past or is it-The use of retrospective accounts as indicators of past strategy. Academy of Management Journal, 35: 848-860.

Hart, H. L. A. 1955. Are there any natural rights? Philosophical Review, 64: 175-191.

Hatch, M. J. 1993. The dynamics of organizational culture. Academy of Management Review, 18: 657-693.

Hendry, J. 2004. Between enterprise and ethics: Business and management in a bimoral society. London: Oxford University Press.
Hume, D. 2000. (First published in 1740.) A treatise of human nature. (Edited by D. F. Norton \& M. J. Norton.) New York: Oxford University Press.

Jensen, M. C., \& Fuller, J. 2002. What's a director to do? Best practices: Ideas and insights from the world's foremost business thinkers: 1-18. Cambridge, MA: Perseus.

Jones, T. M. 1995. Instrumental stakeholder theory: A synthesis of ethics and economics. Academy of Management Review, 20: 404-437.

Jones, T. M., \& Wicks, A. C. 1999. Convergent stakeholder theory. Academy of Management Review, 24: 206-222.

Katz, D., \& Kahn, R. L. 1978. The social psychology of organizations (2nd ed.). New York: Wiley.

Kotter, J. R, \& Heskett, J. L. 1992. Corporate culture and performance. New York: Free Press.

Langtry, B. 1994. Stakeholders and the moral responsibilities of business. Business Ethics Quarterly, 4: 431-443.

Lord, R. G., Brown, D. J., \& Freiberg, S. J. 1999. Understanding the dynamics of leadership: The role of follower selfconcepts in the leader follower relationship. Organizational Behavior and Human Decision Processes, 78: 167203.

March, J. G., \& Simon, H. A. 1958. Organizations. New York: Wiley.

Martin, J. 2002. Organizational culture: Mapping the terrain. Newbury Park, CA: Sage.

McClintock, C. G. 1978. Social values: Their definition, measurement, and development. Journal of Research and Development in Education, 12(1): 121-137.

Messick, D. M., \& McClintock, C. G. 1968. Motivational bases of choice in experimental games. Journal of Experimental Social Psychology, 4: 1-25.

Mill, J. S. 1998. (First published in 1863.) Utilitarianism. (Edited by R. Crisp.) New York: Oxford University Press.

Mitchell, R. K., Agle, B. R., \& Wood, D. J. 1997. Toward a theory of stakeholder identification and salience: Defining the principle of who and what really counts. Academy of Management Review, 22: 853-886.

Paul, J., Costley, D. L., Howell, J. P., Dorfman, P. W., \& Trafimow, D. 2001. The effects of charismatic leadership on followers' self-concept accessibility. Journal of Applied Social Psychology, 31: 1821-1844.

Pettigrew, A. M. 1979. On studying organizational cultures. Administrative Science Quarterly, 24: 570-581.

Phillips, R. A. 1997. Stakeholder theory and a principle of fairness. Business Ethics Quarterly, 7: 51-66.

Phillips, R. A. 2003. Stakeholder legitimacy. Business Ethics Quarterly, 13: 24-41.

Pincoffs, E. L. 1986. Quandaries and virtues: Against reductivism in ethics. Lawrence: University Press of Kansas.

Post, J. E., Preston, L. E., \& Sachs, S. 2002. Redefining the corporation: Stakeholder management and organizational wealth. Stanford. CA: Stanford University Press.

Quinn, D. P., \& Jones, T. M. 1995. An agent morality view of 
business policy. Academy of Management Review, 20: $22-42$.

Rawls, J. 1964. Legal obligation and the duty of fair play. In S. Hook (Ed.), Law and philosophy: 3-18. New York: New York University Press.

Rawls, J. 197la. A theory of justice. Cambridge, MA: Belknap Press of Harvard University Press.

Rawls, J. 1971b. Justice as reciprocity. In S. Freeman (Ed.), John Rawls: Collected papers: 190-224. Cambridge, MA: Harvard University Press.

Schein, E. H. 1985. Organizational culture and leadership. San Francisco: Jossey-Bass.

Schein, E. H. 1990. Organizational culture. American Psychologist, 45: 109-119.

Shamir, B., House, R. J., \& Arthur, M. B. 1993. The motivational effects of charismatic leadership-A self-concept based theory. Organization Science, 4: 577-594.

Shamir, B., Zakay, E., Breinin, E., \& Popper, M. 1998. Correlates of charismatic leader behavior in military units: Subordinates' attitudes, unit characteristics, and superiors' appraisal of leader performance. Academy of Management Journal, 41: 387-409.

Smith, A. 1937. (First published in 1776.) An inquiry into the nature and causes of the wealth of nations. New York: Modern Library.

Sparks, J. R., \& Schenk, J. A. 2001. Explaining the effects of transformational leadership: An investigation of the effects of higher-order motives in multilevel marketing organizations. Journal of Organizational Behavior, 22: 849-869.

Suchman, M. C. 1995. Managing legitimacy: Strategic and institutional approaches. Academy of Management Review, 20: 571-610.
Swidler, A. 1986. Culture in action: Symbols and strategies. American Sociological Review, 51: 273-286.

Tetlock, P. E., Kristel, O. V., Elson, S. B., Green, M. C., \& Lerner, J. S. 2000. The psychology of the unthinkable: Taboo trade-offs, forbidden base rates, and heretical counterfactuals. Journal of Personality and Social Psychology, 78: 853-870.

Treviño, L. 1990. A cultural perspective on changing and developing organizational ethics. Research on Organizational Change and Development, 4: 195-230.

Treviño, L. K., \& Weaver, G. R. 2003. Managing ethics in business organizations: $A$ social science perspective. Stanford, CA: Stanford Business Books.

Trice, H. M., \& Beyer, J. M. 1984. Studying organizational cultures through rites and ceremonials. Academy of Management Review, 9: 653-669.

VandenBerg, P. T., \& Wilderom, C. P. M. 2004. Defining, measuring, and comparing organisational cultures. Applied Psychology: An International Review, 53: 570-582.

Victor, B., \& Cullen, J. B. 1988. The organizational bases of ethical work climates. Administrative Science Quarterly, 33: 101-125.

Walzer, M. 1994. Thick and thin: Moral argument at home and abroad. Notre Dame, IN: University of Notre Dame Press.

Weick, K. E. 2004 Mundone poetics: Searching for wisdom in organization studies. Organization Studies, 25: 653-668.

Wicks, A. C., Gilbert, D. R., Jr., \& Freeman, R. E. 1994. A feminist reinterpretation of the stakeholder concept. Business Ethics Quarterly, 4: 475-498.

Willer, D., Lovaglia, M. J., \& Markovsky, B. 1997. Power and influence: A theoretical bridge. Social Forces, 76: 571603.

Williamson, O. E. 1985. The economic institutions of capitalism. New York: Free Press.

Thomas M. Jones (rebozo@u.washington.edu) is the Boeing Professor of Business Management at the University of Washington. He received his Ph.D. from the University of California, Berkeley. His research interests include business ethics and competitive strategy, stakeholder theory, corporate social performance, and alternative objective functions for corporations.

Will Felps (willf@u.washington.edu) is pursuing a doctorate in organizational behavior at the University of Washington. His research focuses broadly on how to build better organizational theories and includes the role of moral identity in organizational decision making, the asymmetric effects of "bad apple" teammates, and the performance implications of stakeholder cultures.

Gregory A. Bigley (gbigley@u.washington.edu) is an associate professor of human resource management and organizational behavior at the University of Washington. He received his Ph.D. from the University of California, Irvine. His research focuses on trust, motivation, leadership, the self, and the social psychological foundations of high-reliability and high-performance organizing. 
Copyright of Academy of Management Review is the property of Academy of Management and its content may not be copied or emailed to multiple sites or posted to a listserv without the copyright holder's express written permission. However, users may print, download, or email articles for individual use. 